\title{
Metagenomic 16S rDNA Targeted PCR-DGGE in Determining Bacterial Diversity in Aquatic Ecosystem
}

\author{
Nur A. Hasan, W. Bari Chowdhury ${ }^{1}$, Niaz Rahim¹, Marzia Sultana ${ }^{1}$, S. Antara Shabnam¹, Volker Mai ${ }^{2}$, Afsar

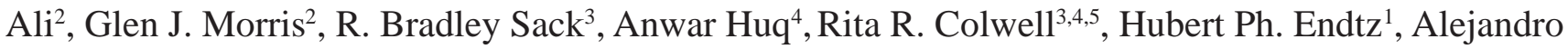 \\ Cravioto ${ }^{1}$, and Munirul Alam ${ }^{1 *}$ \\ ${ }^{1}$ International Center for Diarrhoeal Disease Research, Bangladesh, Dhaka, Bangladesh; ${ }^{2}$ Emerging Pathogen Research Institute, University of Florida, \\ Gainesville, FL; ${ }^{3}$ Johns Hopkins Bloomberg School of Public Health, Baltimore, MD; ${ }^{4}$ Maryland Pathogen Research Institute, University of Maryland, College \\ Park, MD; ${ }^{5}$ University of Maryland Institute for Advanced Computer Studies, College Park, MD, USA.
}

(Received 27 November 2010; Accepted 5 February 2011)

\begin{abstract}
Bacterial numbers in surface water samples, collected randomly from six different water bodies, were estimated by acridine orange direct counting (AODC) and conventional culture-based heterotrophic plate counting (HPC). Bacterial genomic DNA was prepared from water samples by employing methods used for stool samples, including the population dynamics, were determined by primer extension of the 16S rDNA (V6/V8 region) using polymerase chain reaction (PCR), followed by denaturing gradient gel electrophoresis (DGGE), a metagenomic tool that is capable of separating unrelated DNAs based on the differences in their sequences and GC contents. The bacterial numbers in water samples ranged from $10^{3}-10^{6} \mathrm{CFU} / \mathrm{mL}$ for HPC and $10^{4}-10^{7}$ cells/ $\mathrm{mL}$ for AODC, showing that a great majority of bacteria prevail as uncultivable which do not respond to culture methods that are used widely for tracking bacterial pathogens. The acridine orange-stained bacteria varied in sizes and shapes, and appeared either as planktonic (solitary) cells or as clusters of biofilms, showing the presence of diverse community under the epifluorescence microscope. The DGGE of the ca. $457 \mathrm{bp}$ amplicons, as confirmed by agarose gel electrophoresis, produced bands that ranged in intensities and numbers from 18 to 31, with each band possibly indicating the presence of one or more closely related bacterial species. The enrichment of pathogenic bacteria in the aquatic ecosystem is known to precede the seasonal diarrhoeal outbreaks; therefore, bacterial community dynamics determined by Metagenomic 16S PCR-DGGE during pre-epidemic enrichment appears promising in predicting the upcoming diarrheal outbreaks.
\end{abstract}

Key words: Metagenomics, 16S rDNA, PCR, DGGE, bacterial community dynamics

\section{Introduction}

Metagenomics, the study of genomes, has been successful in elucidating the complex microbial communities present in the natural ecosystem ${ }^{1,2}$. The use of conventional culture-based methods is limited to estimation of bacterial population numbers from mixed microbial communities, and thus cannot represent much of the microbial world, as indicated by the inconsistency in "the great plate count anomaly"3,4. The culturable fraction of bacteria from aquatic environments has been found to be ten to a thousand times lower than those cultured from the soil ${ }^{3}$. However, over the last several decades, the development of ribosomal RNA (rRNA) phylotyping in identifying and enumerating microbes from the environment has shown that the variability within the highly conserved regions of rRNA sequences increases as the evolutionary distance increases between two organisms, thus providing the means to determine phylogenetic relationships between microorganisms ${ }^{5-12}$. Metagenomic rDNA-based techniques have employed the advanced molecular technique of polymerase chain reaction $(\mathrm{PCR})^{13}$, such as universal primer PCR targeted against 16S rDNA, followed by separation of amplicons using Denaturing Gradient Gel electrophoresis (DGGE) and Temporal Temperature Gradient Gel electrophoresis (TTGE) to analyze complex microbial communities present in environmental samples $^{19-22}$, including the soil ${ }^{14-18}$, water, and the human distal gut microbiome $23-26$.

In DGGE, denaturation of DNA strand depends on nucleotide sequence composition, therefore PCR products with different compositions but of same length will migrate different distances when exposed to a gradient of denaturing conditions, resulting in distinct fingerprints during separation ${ }^{6}$.

In the present study, the conventional culture and Acridine Orange Direct Count (AODC) techniques were used to estimate the bacterial population size in water samples randomly collected from six sites, most being located at the Dhaka city. In addition, 16S rDNA PCR DGGE, which has been previously used

*Corresponding Author:

Munirul Alam, Enteric and Food Microbiology Laboratory, Lab Sciences Division, International Center for Diarrheal Disease Research, Bangladesh, Dhaka, Bangladesh, Tel.: +88-02-8860523 - 32 Fax: +88-02-8812529, 8821116, E-Mail. : munirul@icddrb.org 
successfully to compare microbial communities in a variety of ecosystems ${ }^{6,21,27-29}$, was performed in order to determine the bacterial community dynamics in the surface water.

\section{Materials and Methods}

\section{Counting of bacteria by HPC and AODC}

Hundred micro-liters of each of the sample were plated onto Heterotrophic Plate Count (HPC) agar plate, which is a nonselective medium, for total culturable bacterial count. For HPC counting, samples were subjected to 10 -fold dilution prior to spread plating. The plates were then incubated at $37^{\circ} \mathrm{C}$ for 18 to 24 hours. Acridine Orange Direct Counting (AODC) was performed according to an earlier described method ${ }^{30}$. The samples were pre-incubated overnight in the dark with $0.025 \%$ yeast extract (Difco Laboratories, Detroit, Michigan) and $0.002 \%$ naldixic acid (Sigma), after which the cells in the samples were fixed with $4 \%$ formaldehyde and diluted 10 -fold in a series. The bacterial cells were stained with Acridine Orange (Sigma, final concentration $0.1 \% \mathrm{w} / \mathrm{v}$ ) for 2 minutes and filtered through black polycarbonate filters (Millipore, pore size 0.2 $\mu \mathrm{m}$, diameter $25 \mathrm{~mm}$ ) which were prestained with Irgalan black dye. The stained bacterial populations on the membrane filters were counted under UV light using an epifluorescent microscope (Carl Zeiss, Axioskop 40). The total bacterial counts were averaged from the bacterial numbers obtained from 20 microscopic fields and the images were captured using a digital camera (AxioCam MRc).

\section{DNA extraction from environmental samples}

The DNA from the environmental samples was isolated using method used for clinical samples. In brief, $100 \mathrm{ml}$ of water samples were centrifuged at $13 \mathrm{k}$ rpm for 10 minutes and filtered through $0.22 \mu \mathrm{m}$ membrane filter. The pellets were retained and the membranes were washed off with $5 \mathrm{ml}$ of buffer A $(50 \mathrm{mM}$ Tris, $5 \mathrm{mM}$ EDTA, pH 8.0) at least three times to recover maximum amount of retained materials. Centrifugation was performed at $13 \mathrm{k}$ rpm for 10 minutes and the pellet was retained, to which $467 \mu \mathrm{l}$ of lysis buffer (100 mM Tris, $100 \mathrm{mM}$ EDTA, 1.5M NaCl, pH 8.0) was added and mixed by repeated inversion for 10 minutes. This was followed by addition of $30 \mu$ of $10 \%$ SDS and mixing by inverting, and incubation at $65^{\circ} \mathrm{C}$ for $15 \mathrm{mins}$ or until a clear solution was obtained. Thirty micro-liters of proteinase $\mathrm{K}(20 \mathrm{mg} / \mathrm{ml})$ was added to the mixture followed by incubation at $37^{\circ} \mathrm{C}$ for $1 \mathrm{hr}$ and addition of $100 \mu \mathrm{l}$ of $5 \mathrm{M} \mathrm{NaCl}$ with thorough mixing. The next step involved addition of CTAB/ $\mathrm{NaCl}$ solution $(80 \mu \mathrm{l})$; this was mixed thoroughly and then incubated at $65^{\circ} \mathrm{C}$ for 10 minutes. Following incubation, the contents were cooled to room temperature and equal volumes of chloroform/isoamyl alcohol was added and mixed thoroughly by repeated inversion. Centrifugation at $12 \mathrm{rpm}$ for 5 minutes produced a clear supernatant which was promptly transferred to a new eppendorf tube, without disturbing the interface. Equal volumes of phenol:chloroform:isoamyl alcohol (25:24:1) mixture were added to the supernatant and mixed by inverting, followed by centrifugation at $13 \mathrm{rpm}$ for 5 minutes. The clear supernatant obtained was subjected to DNA precipitation by addition of 0.6 volume of isopropanol, accompanied with vigorous shaking of the tubes until stringy white DNA precipitates were visible.

The extracted community DNA was purified by adding $20 \mu \mathrm{l}$ sodium acetate and $300 \mu \mathrm{l}$ absolute alcohol, after which they were left for one hour at $-80^{\circ} \mathrm{C}$ and centrifuged for 10 minutes at 13.2 rpm. The pellet was retained with the addition of $200 \mu \mathrm{l}$ of $70 \%$ ethanol and centrifugation at $13 \mathrm{~K}$ rpm for 10 minutes. The saved pellet was dissolved with $200 \mu \mathrm{l}$ of $70 \%$ alcohol and centrifuged at $13 \mathrm{~K}$ rpm for 10 minutes. Finally the pellet was air-dried.

DNA fragments for DGGE analyses were obtained from PCR with primers specific for conserved regions of the 16S rRNA gene. The primers with their respective sequences are provided in Table 1.

Table 1: Primers used for 165 rDNA PCR-DGGE

\begin{tabular}{ll}
\hline Primer & Sequence \\
\hline 6968 GC (V6/V8) & 5’ - AA CGC GAA GAA CCT TAC - 3’ \\
L1401 & 3’- GCG TGT GTA CAA GAC CC - 5’ \\
\hline
\end{tabular}

PCR

The oligonucleotide primers 6968 GC which amplify variable regions 6 and 8 (V6/V8) and L1401 were used to selectively amplify 16S rDNA genes of eubacteria. A 40 nucleotide GC-rich sequence was attached to the 5'- end of primer 6968 GC to improve the detection of sequence variation in amplified DNA fragments by subsequent DGGE. PCR amplification was performed in a thermal cycler (PTC-200 Peltier Thermal Cycler, MJ Research, Cetus, USA).

Each sample consisted of $50 \mathrm{ng}$ of extracted DNA with $0.05 \mu \mathrm{M}$ of each of PCR primer, 200 $\mu \mathrm{M}$ each of dNTP, $1.5 \mathrm{mM} \mathrm{MgCl}$, $1.25 \mathrm{U}$ of Taq DNA polymerase in storage buffer A (Promega Co., USA), $5 \mu$ l of thermophilic 10X PCR buffer and sterile water added to make it upto $50 \mu \mathrm{l}$. The program consisted of 2 minutes of initial DNA denaturation and enzyme activation at $94^{\circ} \mathrm{C}$. This was followed by 34 cycles, with each cycle consisting of 30 seconds of denaturation at $94^{\circ} \mathrm{C}, 30$ seconds of annealing at $56^{\circ} \mathrm{C}$, 1 minute of elongation at $68^{\circ} \mathrm{C}$, and a final elongation for 7 minutes at $68^{\circ} \mathrm{C}$.

The PCR amplified products were separated in a 1\% agarose gel by using Horizon 11-14 (Life Technologies, USA) electrophoresis apparatus. The gel was stained with ethidium bromide $(10 \mathrm{mg} /$ $\mathrm{ml}$ ) and visualized under a UV trans-illuminator.

\section{Denaturing Gradient Gel Electrophoresis (DGGE)}

DGGE of the $16 \mathrm{~S}$ rDNA amplicons $(n=6)$, which had an approximate size $457 \mathrm{bp}$, was performed by following the methods, as described elsewhere ${ }^{6,21,26}$. The characteristic profiles of the community obtained by DGGE separation of the PCR amplicons were analyzed. 
The DCode ${ }^{\circledR}$ Universal Mutation Detection System with gradient former model 475 was used according to the manufacturer's instructions (Bio-Rad). The acrylamide concentration in the gel was $6 \%$ and the denaturing gradient was between 40 and $50 \%$. Both the $100 \%$ and $0 \%$ denaturant solution contained $7 \mathrm{M}$ urea with $40 \%$ (v/v) formamide, 6\% acrylamide/bis-acrylamide (37.5:1) and 0.5X Tris-acetate EDTA (TAE) buffer at pH 8.0 in ultra pure water. Fifteen microliters of purified PCR amplicons were mixed with equal volumes of loading buffer and loaded to gel wells. The gels were run in $0.5 \mathrm{X}$ TAE buffer at $60^{\circ} \mathrm{C}$ for 16 hours at $65 \mathrm{~V}$ as per the previously established method $^{31}$, followed by 30 minute incubation in the dark, staining with $1 \mu \mathrm{l}$ of SYBR ${ }^{\mathrm{TM}}$ Gold and visualizing under UV light with the Gel Doc 2000 System (Bio-Rad).

\section{Results and Discussion}

\section{Estimation of bacterial counts using HPC and AODC}

The number of total culturable bacteria estimated by heterotrophic plate counts (HPC) varied from $10^{3}-10^{6} \mathrm{CFU} / \mathrm{ml}$ (Fig. 1). The total number of bacteria, as determined by Acridine Orange Direct Counting (AODC), varied from $10^{4}-10^{7}$ cells $/ \mathrm{ml}$, as displayed in Fig. 1. The comparative data revealed that the actual bacterial number determined by AODC was higher by 1 to 2 logs than that for HPC (Fig. 1), and this seemed to be in accordance to an earlier report that more than $99 \%$ of the bacteria do not respond to conventional (routine) culture, and are thus nonculturable ${ }^{4}$.

The micrographs of the Acridine Orange-stained samples showed the presence of bacterial cells that appear in various sizes and

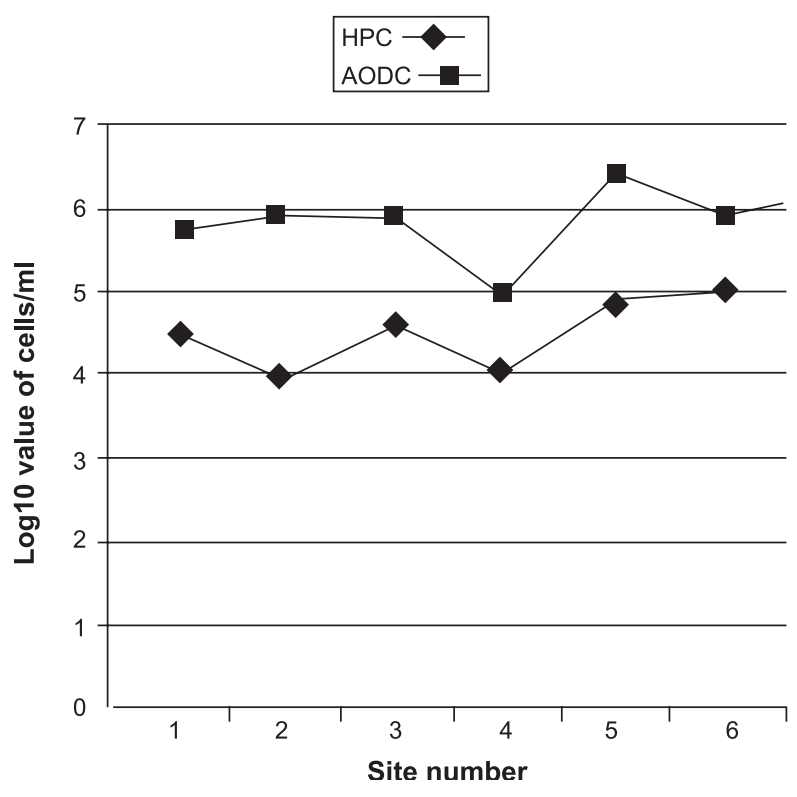

Fig 1: Logarithmic graph showing line diagram of AODC and HPC counts of bacteria occurring in natural surface water samples.

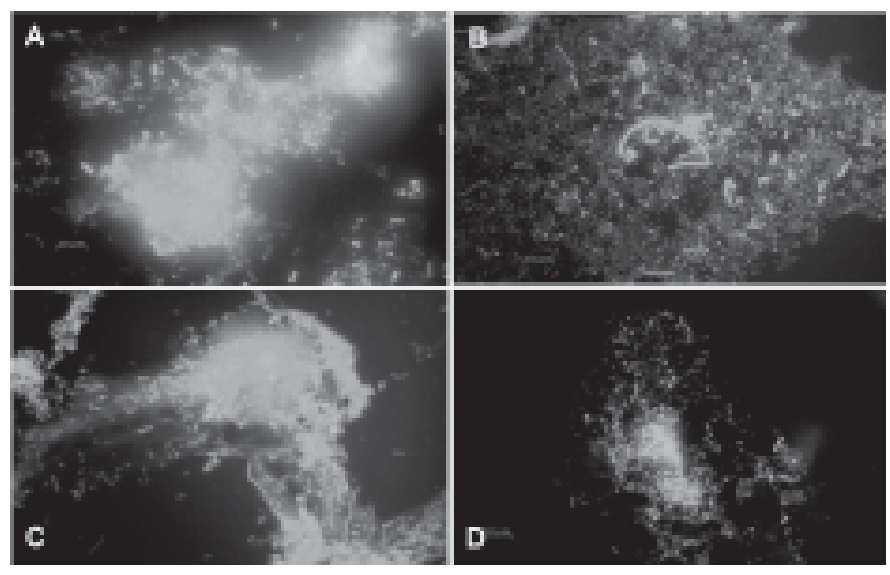

Fig 2: Epifluorescence micrographs of microbial communities showing bacterial cells stained with Acridine Orange dye, found in the surface water samples. Images were captured digitally (Carl Zeiss, Axioskop 40).

shapes (rods, spheres, etc.), either free-living, or in clusters of biofilms, as depicted in Figs. 2. These images provide an in situ evidence of how bacterial communities modulate their survival in the natural aquatic ecosystem that serves as niche for many bacterial enteric pathogens. It has already been established that in non culturable states, bacteria survive without responding to conventional culture techniques and mostly remain undetected $^{32,34}$. They undergo morphological changes, whereby the rod shapes of bacteria turn coccoid by reducing in size, including secretion of polysaccharides or extracellular matrices (biofilms) for protection against adverse environmental conditions $^{34}$. Similarly, the nonculturable states as a means to overcome stresses has been well documented in several enteric pathogens, including Vibrio cholerae, the cause of cholera ${ }^{32,34}$. Although little is known about the mechanism of how nonculturable bacteria regain culturability to multiply and increase their number to be able to initiate seasonal diarrheal epidemics, the characteristic seasonality and the isolation of culturable $V$. cholerae prior to cholera epidemics in Bangladesh indicate a seasonal shift in the bacterial flora in the aquatic environments that serve as the reservoir for them ${ }^{34}$. Evidences in the past suggested that the nonculturable $V$. cholerae cells retain the metabolic activity within biofilms and can revert to culturability when favorable conditions recur, and can pose a major health risks for human ${ }^{32-34}$. Thus, the nonculturable bacterial communities that prevail in the aquatic ecosystem requires continuous monitoring to be able to track the floral shifts resulted by competition and proliferation of a particular population of major public health concern ${ }^{34}$. As evident from results of the current study, the major limitations of the HPC and AODC may be that none of these methods precisely and reliably reflect the seasonal changes that bring about changes in bacterial community dynamics in the aquatic ecosystem. 


\section{Agarose gel electrophoresis of 165 rDNA amplified by PCR}

The PCR using primers that successfully amplified the V6/V8 regions of 16S rDNA produced amplicons of an approximate size $457 \mathrm{bp}$ in all water samples tested. The six samples that produced the PCR amplicons were further analyzed by DGGE for the determination of bacterial community dynamics.

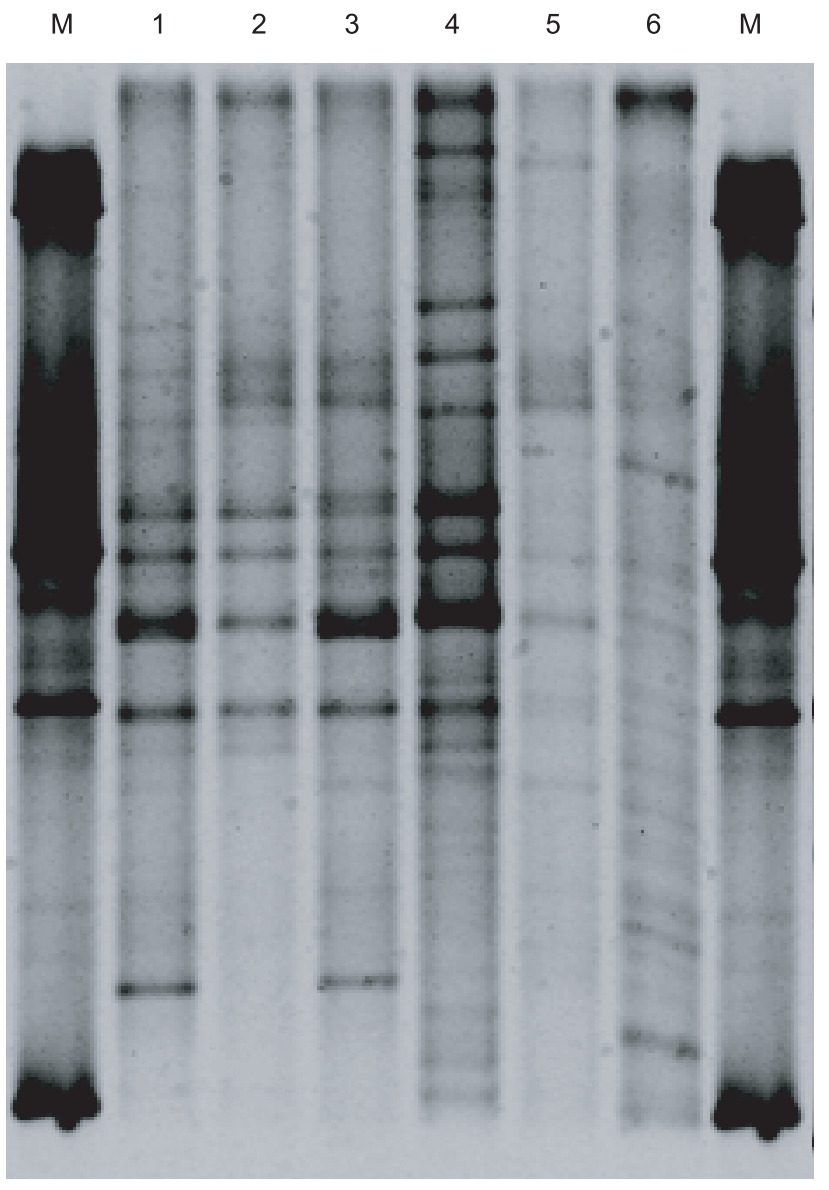

Fig 3: The 16s rDNA amplified from natural surface water samples by PCR were analyzed by denaturing gradient gel ( $40 \%$ $-50 \%$ ) electrophoresis (DGGE).

Lanes M: Marker; Lane 1: Jahurul Haq Hall, Dhaka University (DU); Lane 2: Fazlul Huque Hall, DU; Lane 3: Jagannath Hall, DU; Lane 4: Mathbaria Pond; Lane 5: Rampura Lake; Lane 6: River Buriganga.

\section{DGGE}

The DGGE band patterns varied between the water bodies; the band numbers ranged from 18 - 31 (Fig. 3).

The maximum number of bands was observed for water sample collected from the Buriganga River, labeled as Site 6, from which 31 bands were obtained. Minimum number of bands $(\mathrm{n}=18)$ were found from Site 5, a lake located in Rampura which was also connected to the sewage system. The variation of band patterns within DGGE profiles, which is dependent on the bacterial population dynamics, may have been influenced by the physical and chemical quality of water, such as the availability of nutrients, since connections of sewage systems with the pond and river waters allow fecal and other domestic and industrial effluents to be washed into the waters. For instance, the maximum number of bands within the DGGE profiles for the river Buriganga can possibly be attributed to the freely flowing, efficiently aerated waters that support greater diversity and enrichment of bacterial communities resulting from the discharge of approximately $15000 \mathrm{~m}^{3}$ of untreated chemical wastes into the water ${ }^{36}$, whereas the minimum number of bands corresponding to the sample collected from the Rampura lake may be highly eutrophic since the stagnant waters are not properly aerated and may not be supportive for the complex microbial communities that usually prevail in surface waters. Based on the DGGE profile, especially the numbers and intensity of the bands in water samples, it may be suggested that the DNA isolation methods used for stool samples was efficient in elucidating the bacterial diversity in the aquatic ecosystem. The recurrent diarrheal diseases that occur endemically in Bangladesh are climate driven, that is, seasonal ${ }^{34}$. Under the changing climate, which is presumed to contribute to infectious diseases, the determination of the bacterial community dynamics in aquatic ecosystem is crucial for understanding the floral shifts that are believed to contribute to the proliferation of a particular population of diarrheal implication ${ }^{34-}$ 35 . Whereas the culture methods fail to detect most bacteria and direct microscopic observation only indicate the physical presence of bacteria, the diverse 16SrDNA bands, some of which appeared as intense bands, represent one or more closely related species in the aquatic ecosystem. This study was limited in that the samples were not tested in length to elucidate the yearly seasonal patterns; nonetheless, the DGGE band patterns will show variations due to seasonal climate change, and the resultant floral shift in the aquatic ecosystem. Therefore, the characteristic DGGE patterns that are likely to recur during the seasonal change can be translated into a prediction model for upcoming diarrhea. The DNA band(s) in the DGGE profiles can be sequenced to provide comprehensive identification of bacteria up to the species level. Nonetheless, the relative positioning and the intensity of bands with reference to DGGE markers can be reliable in predicting the emergence of a bacterial species of epidemic implication. Further work is in progress in our laboratory.

\section{Acknowledgements}

This research was funded by National Institutes of Health Grant No. 1RO1A13912901, under collaborative agreements between the Johns Hopkins Bloomberg School of Public Health, the University of Maryland, College Park, and the International Center for Diarrheal Disease Research, Bangladesh (ICDDR,B). ICDDR,B acknowledges with gratitude the commitment of NIID, NOAA, and NIH to the Center's research efforts. ICDDR,B also gratefully acknowledges the following donors which provide unrestricted support to the Centre's research efforts: Australian Agency for International Development (AusAID), Government of the People's Republic of Bangladesh, Canadian International Development Agency (CIDA), Embassy of the Kingdom of the 
Netherlands (EKN), Swedish International Development Cooperation Agency (SIDA), and the Department for International Development, UK (DFID).

\section{References}

1. Pace NR. 1997. A Molecular View of Microbial Diversity and the Biosphere. Science. 276: 734 - 740.

2. Handelsman J, Rondon MR, Brady SF, Clardy J and Goodman RM. 1998. Molecular biological access to the chemistry of unknown soil microbes: a new frontier for natural products. Chem Biol. 5(10): R245 - R249.

3. Staley JT and Konopka A. 1985. Measurement of in situ activities of nonphotosynthetic microorganisms in aquatic and terrestrial habitats. Annu Rev Microbiol. 39: 321-346.

4. Handelsman J. 2004. Metagenomics: Application of Genomics to Uncultured Microorganisms. Microbiol Mol Biol Rev. 68(4): 669 - 685.

5. Woese CR. 1987. Bacterial evolution. Microbiol Rev. 51: 221-271.

6. Nakatsu, CH, Torsvik V and Øvreås L. 2000. Soil Community Analysis Using DGGE of 16S rDNA Polymerase Chain Reaction Products. Soil Sci Soc Am J. 64: 1382-1388.

7. Pace NR, Stahl DA, Lane DJ and Olsen GJ. 1985. Analyzing natural microbial populations by rRNA sequences. ASM News. 51: 4-12.

8. Lane DJ, Pace B, Olsen GJ, Stahl DA, Sogin ML and Pace NR. 1985. Rapid determination of $16 \mathrm{~S}$ ribosomal RNA sequences for phylogenetic analyses. PNAS USA. 82: 6955 - 6959.

9. Stahl DA, Lane DJ, Olsen GJ and Pace NR. 1985. Characterization of a Yellowstone hot spring microbial community by 5S rRNA sequences. Appl Environ Microbiol. 49: 1379 - 1384.

10. Pace NR, Stahl DA, Lane DJ and Olsen GJ. 1986. The analysis of natural microbial populations by ribosomal RNA sequences. Adv Microb Ecol. 9: $1-55$.

11. Pace NR. 1997. A molecular view of microbial diversity and the biosphere. Science. 276: 734 - 740 .

12. National Academies of Sciences (NAS) Report - Committee on Metagenomics: Challenges and Functional Applications 2007. The New Science of Metagenomics: Revealing the Secrets of Our Microbial Planet. http://www.nap.edu/catalog/11902.html

13. Mullis KB. 1990. The Unusual Origin of the Polymerase Chain Reaction. Sci Am. 262(4): 56 - 61.

14. Field KG, Gordon D, Wright T, Rappe M, Urback E, Vergin K and Giovannoni SJ. 1997. Diversity and depth-specific distribution of SAR11 cluster rRNA genes from marine planktonic bacteria. Appl Environ Microbiol. 63(1): 63-70.

15. Garcia-Martinez J and Rodriguez-Valera F. 2000. Microdiversity of uncultured marine prokaryotes: the SAR11 cluster and the marine Archaea of Group I. Mol Ecol. 9(7): 935-48.

16. Rappe MS, Connon SA, Vergin KL and Giovannoni SJ. 2002. Cultivation of the ubiquitous SAR11 marine bacterioplankton clade. Nature. 418(6898): 630-3.

17. Sait M, Hugenholtz P and Janssen PH. 2002. Cultivation of globally distributed soil bacteria from phylogenetic lineages previously only detected in cultivation-independent surveys. Environ Microbiol. 4(11): 654-66.

18. Brown MV and Fuhrman JA. 2005. Marine bacterial microdiversity as revealed by internal transcribed spacer analysis. Aquat Microb Ecol. 41:1523.

19. Muyzer G, deWaal EC and Uitterlinden AG. 1993. Profiling of complex microbial populations by denaturing gradient gel electrophoresis analysis of polymerase chain reaction-amplified genes coding for 16S rRNA. Appl Environ Microbiol. 59: 695 - 700.
20. Muyzer GA, Teske A, Wirsen CO and Jannasch HW. 1995. Phylogenetic relationships of Thiomicrospora species and their identification in deepsea hydrothermal vent samples by denaturing gradient gel electrophoresis of 16S rDNA fragments. Arch Microbiol. 164: 165-172.

21. Ferris MJ, Muyzer G and Ward DM. 1996. Denaturing gradient gel electrophoresis profiles of 16S rRNA-defined populations inhabiting a hot spring microbial mat community. Appl Environ Microbiol. 62: 340 346.

22. Torsvik V, Daae FL, Sandaa RA and Øvreås L. 1998. Novel techniques for analysing microbial diversity in natural and perturbed environments. J Biotech. 64: 53 - 62.

23. Muyzer G, Hottentrager S, Teske A and Wawer C. 1996. Denaturing gradient gel electrophoresis of PCR-amplified 16S rDNA - A new molecular approach to analyse the genetic diversity of mixed microbial communities. Mol Microb Ecol Manual. 4: 1- 23.

24. Yoshino K, Nishigaki K and Husimi Y. 1991. Temperature sweep gel electrophoresis: a simple method to detect point mutations. Nucl Acids Res. 19(11): 31-53.

25. Venter JC, Remington K, Heidelberg JF, Halpern AL, Rusch D, Eisen JA, Wu D, Paulsen I, Nelson KE, Nelson W, Fouts DE, Levy S, Knap AH, Lomas MW, Nealson K, White O, Peterson J, Hoffman J, Parsons R, Baden-Tillson H, Pfannkoch C,. Rogers YH and Smith HO. 2004. Environmental genome shotgun sequencing of the Sargasso Sea. Science. 304: $66-74$.

26. Gill SR, Pop M, DeBoy RT, Eckburg PB, Turnbaugh PJ, Samuel BS, Gordon JI, Relman DA, Fraser-Liggett CM and Nelson KE. 2006. Metagenomic Analysis of the Human Distal Gut Microbiome. Science. 312: 1355- 1359.

27. Teske AC, Wawer G, Muyzer G and Ramsing NB. 1996. Distribution of sulfate-reducing bacteria in a stratified fjord (Mariager Fjord, Denmark) as evaluated by most-probable-number counts and denaturing gradient gel electrophoresis of PCR-amplified ribosomal DNA fragments. Appl Environ Microbiol. 62:1405 - 1415.

28. Ferris MJ and Ward DM. 1997. Seasonal distributions of dominant $16 \mathrm{~S}$ rRNA-defined populations in a hot spring microbial mat examined by denaturing gradient gel electrophoresis. Appl Environ Microbiol. 63: 1375 $-1381$.

29. Øvreås L, Forney L, Daae FL and Torsvik V. 1997. Distribution of bacterioplankton in meromictic Lake Saelenvannet, as determined by denaturing gradient gel electrophoresis of PCR-amplified gene fragments coding for 16S rRNA. Appl Environ Microbiol. 63(9): 3367 - 3373.

30. Hobbie JE, Daley RJ and Jasper S. 1977. Use of Nucleopore Filters for Counting Bacteria by Fluorescence Microscopy. Appl Environ Microbiol. 33(5): 1225 - 1228.

31. Muyzer G, Brinkhoff T, Nubel U, Santegoeds C, Schafer H and Wawer C. (1998). Denaturing gradient gel electrophoresis (DGGE) in microbial ecology. Mol Microb Ecol Manual. 3(4): 1-27.

32. Xu H-S, Roberts N, Singleton FL, Attwell RW, Grimes DJ and Colwell RR. 1982. Survival and viability of nonculturable Escherichia coli and Vibrio cholerae in the estuarine and marine environment. Microb Ecol. 8(4): 313 - 323.

33. Colwell RR and Huq A. 1994. In: Vibrio cholerae and Cholera: Molecular to Global Perspectives, ed. Wachsmuth I. K., Blake P. A. and Olsvik O. (Am Soc Microbiol, Washington, DC), 117 - 133.

34. Alam M, Sultana M, Balakrish Nair G, Siddique AK, Hasan NA, Sack RB, Sack DA, Ahmed KU, Sadique A, Watanabe H, Grim CJ, Huq A and Colwell RR. 2007. Viable but nonculturable Vibrio cholerae O1 in biofilms in the aquatic environment and their role in cholera transmission. PNAS 104(45): 17801-17806.

35. Politzer R. 1959. Cholera. WHO Monograph Series (World Health Organization, Geneva) 43.

36. Arias-Barreiro CR, Nishizaki H, Okubo K and Mori IC. 2010. Ecotoxicological characterization of tannery wastewater in Dhaka, Bangladesh. J Environ Biol. 31: 471- 475. 